\title{
The Comparative Study of Adaptation Measure to Sea Level Rise in Thailand
}

\author{
Sompratana Ritphring ${ }^{1}$, Pattrakorn Nidhinarangkoon ${ }^{1, *}$, Keiko Udo ${ }^{2}$ and Hiroaki Shirakawa ${ }^{3}$ \\ 1 Department of Water Resources Engineering, Kasetsart University, Bangkok 10900, Thailand; fengstr@ku.ac.th \\ 2 International Research Institute of Disaster Science, Tohoku University, Sendai 9808572, Japan; \\ udo@irides.tohoku.ac.jp \\ 3 Graduate School of Environmental Studies, Nagoya University, Nagoya 4648601, Japan; \\ sirakawa@urban.env.nagoya-u.ac.jp \\ * Correspondence: pattrakorn.n@gmail.com
}

Citation: Ritphring, S.;

Nidhinarangkoon, P.; Udo, K.; Shirakawa, H. The Comparative Study of Adaptation Measure to Sea Level Rise in Thailand. J. Mar. Sci. Eng. 2021, 9, 588. https://doi.org/ $10.3390 /$ jmse9060588

Academic Editor: João Miguel Dias

Received: 4 May 2021

Accepted: 25 May 2021

Published: 28 May 2021

Publisher's Note: MDPI stays neutral with regard to jurisdictional claims in published maps and institutional affiliations.

Copyright: (C) 2021 by the authors Licensee MDPI, Basel, Switzerland. This article is an open access article distributed under the terms and conditions of the Creative Commons Attribution (CC BY) license (https:// creativecommons.org/licenses/by/ $4.0 /)$.
Abstract: In the 21st century, global sea level rise associated with climate change will affect beach areas, which provide a number of benefits that include benefits to the recreational sector of the economy. In Thailand, the adoption of structural measures in order to slow down beach erosion and handle the impact of sea level rise is commonly implemented. However, structural measures often bring about negative effects on nearby coastal areas. For this reason, suitable adaptation measures should be determined, in order to protect beach areas and to sustain the tourism carrying capacity of the beach. This study analyzed historical shoreline changes using satellite images, and assessed beach value with the hedonic pricing method. We used a benefit-cost ratio analysis to evaluate the economic valuation assessment of Pattaya beach and Chalatat beach. The results showed that the beach values of Pattaya beach and Chalatat beach were 1,072,250 and 92,092 USD, respectively. The benefit-cost ratio analysis proposed that it is worth implementing beach nourishment for the adaptation measure to address all climate change scenarios. In response to climate change, recommendations could be applied to support beach tourism.

Keywords: climate change; tidal correction; beach erosion; beach nourishment; seawall; coastal setback; Pattaya beach; Chalatat beach

\section{Introduction}

Coastal areas provide benefits to humans and coastal ecosystems. Beaches act as buffers between the ocean and land, and tend to change dynamically in response to natural and human activities. The Intergovernmental Panel on Climate Change (IPCC) reports that global sea level rise associated with climate change is expected to be between $8-16 \mathrm{~mm} / \mathrm{y}$ in the 21st century [1]. Between 1972 and 2011, measurements of sea levels from 22 tide gauge stations in the Gulf of Thailand and the Andaman Sea showed that sea levels had risen at an average rate of $6.5 \mathrm{~mm} / \mathrm{y}$ [2]. Using the Bruun rule, the national beach loss rate projections between 2081-2100 are $45.8 \%$ for a scenario in which representative concentration pathway (RCP) is 2.6 , and $71.8 \%$ for a scenario in which RCP is 8.5 . In addition, 23 of 64 beach zones in Thailand will be completely lost during this same time period [3].

Shoreline retreat associated with sea level rise affects the tourism carrying capacity (TCC), which is a tool used to analyze beach development [4]. Many studies use TCC to assess the management of areas for tourism and recreation. For example, on South Andaman Island (India), TCC varied with changes between the physical and biotic environments [5]. Another study of TCC at Fandoqloo in Iran estimated TCC by using physical, real, and effective carrying capacity [6]. The current effective carrying capacity (ECC) of Pattaya beach is about 200,000 visitors/day, whereas the ECC of Chalatat beach is 49,000 visitors/day, based on our previous study of the impact of sea level rise on TCC in 
Thailand [7]. Adaptation measures should be applied to help retain beach area and support the recreational needs associated with the Pattaya beach and Chalatat beach.

In this study, beach nourishment, seawall and setback were chosen to determine the suitable adaption measures to sea level rise for tourism beaches. The solutions that involve hard structures for beach protection affect the beach and nearby areas, and several coastal protection agencies have used beach nourishment adaptations to deal the impacts of beach erosion. Examples include more than 30 beaches in Florida, North Atlantic Coast, U.S. Pacific Coast (all USA) and Quintana Roo (Mexico) [8,9]. The seawall is one of the widely used coastal structures that protect the areas behind the wall from waves effect. It stabilizes the position of the upland. The coastal setback is the buffer area in which permanent constructions are not allowed [10]. The setback line was determined to save the coastal development areas from the natural areas and hazard such as erosion, storm surge and sea level rise. For example, Denmark, Canada, France, Germany, Australia selected setback to improve the coastal zone management [11,12].

In Thailand, beach nourishment was the earliest strategy used at Pattaya beach (Chonburi province) in 2017, with a total volume of $362,200 \mathrm{~m}^{3}$ of sediment taken from offshore. This project's construction cost was approximately 14 million USD. In Songkhla, the ongoing beach nourishment construction cost at Chalatat beach was approximately 8.98 million USD for $40,929 \mathrm{~m}^{3}$ of sediment taken from the downdrift side of the beach. There are various seawall constructions along the Thai coast, of which the average construction price is 3,231,642 USD/ km (https:/ / govspending.data.go.th; accessed on 1 September 2020). Since then, several coastal areas have used seawalls to combat erosion, but it was not found to protect the beach fronting and adjacent seawall [13-15]. However, setback regulation has not yet been implemented in Thailand.

The economic value of ocean and beach tourism in Thailand is 30\% of the country's gross domestic product (GDP), and the value of tourism is about 2.81 billion USD/y (source: www.bltbangkok.com; accessed on 1 September 2020). Beaches are natural resources with intrinsic value, and as such, it is difficult to calculate their value. However, beach value can be assessed with the hedonic pricing method, which is an indirect method used to calculate a value that cannot be observed directly, but can be deduced from the value of observable market transactions. Considering that the value of characteristics is non-observable because it cannot be traded individually in the market [16], hedonic pricing models have been widely used to analyze the effect of factors on room rates [17].

The aim of this study to compare the adaptation measures to sea level rise in Thailand comprising beach nourishment, seawall and coastal setback. The shoreline changes was detected by using satellite images with the tidal correction method. In addition, we estimated the beach value with the hedonic pricing method. Shoreline retreat associated with sea level rise and TCC were analyzed in our previous study [7]. Beach nourishment was designed to restore the shoreline changes due to sea level rise back to the present situation in order to sustain the beach areas and TCC. Seawall is the adaptation that protects the beach and areas behind the seawall, but it does not cover the nearby areas. The coastal setback was determined to be the adaptation policy, which made the shoreline retreat by doing nothing. The economic valuation assessment was conducted using a benefit-cost ratio analysis that determined the beach value and the beach nourishment construction cost needed to protect the beach from sea level rise and beach erosion. The results can be applied more broadly for the planning and management of coastal tourism.

\section{Study Areas and Data}

\subsection{Study Areas}

The study areas are sandy beaches, which are located in Pattaya beach and Chalatat beach in Thailand (Figure 1). These coastal areas experience the effects of northeastern monsoons from the middle of October to the middle of February, which cause heavy rain and high waves. The average foreshore beach slope is 6.43 degrees for Chalatat beach and 9.34 degrees for Pattaya beach. The average sediment grain size is $0.27 \mathrm{~mm}$ 
for Chalatat beach and $0.30 \mathrm{~mm}$ for Pattaya beach. Pattaya beach represents a beach dominated by international tourism, whereas Chalatat beach represents a beach dominated by domestic tourism.

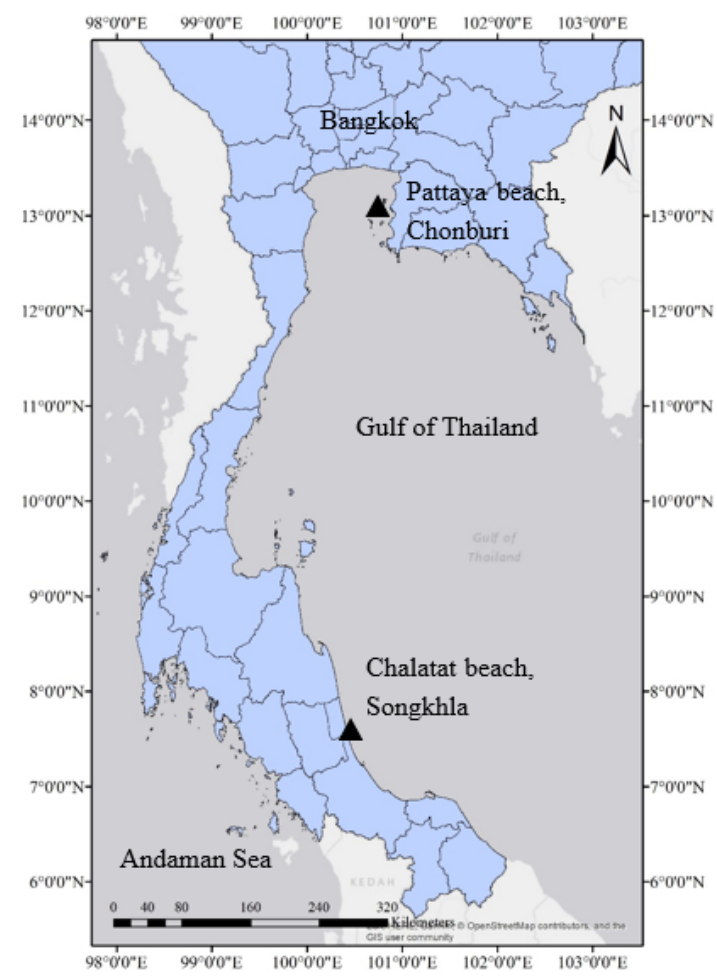

Figure 1. Study areas.

\subsection{Data}

Satellite images were taken from Google Earth. In addition, this study observed foreshore beach slope and sediment grain size. TCC and beach areas for four climate change scenarios, hotel room price, beach nourishment construction cost, seawall construction cost and cost of construction price for the setback were calculated.

\subsubsection{Satellite Images}

In this study, satellite images from Google Earth were used to measure shoreline position for Pattaya and Chalatat beaches for the dates listed in Table 1.

Table 1. Time series of satellite images.

\begin{tabular}{cc}
\hline & Study Areas \\
\hline Pattaya Beach & Chalatat Beach \\
\hline 11 December 2002 & 31 December 2004 \\
5 January 2005 & 16 March 2006 \\
29 December 2006 & 3 October 2007 \\
21 December 2009 & 8 August 2010 \\
8 April 2010 & 31 July 2011 \\
16 October 2014 & 17 April 2014 \\
19 August 2015 & 6 April 2015 \\
8 February 2016 & 9 July 2017 \\
30 December 2017 & 6 August 2018 \\
16 February 2019 & \\
\hline
\end{tabular}


2.2.2. Tourism Carrying Capacity, Projected Shoreline Retreat, and Beach Areas for Each Climate Change Scenario

In our previous study of the impact of sea level rise on TCC in Thailand, we analyzed the shoreline retreat using the Bruun rule, beach area from satellite images, and TCC, which are physical carrying capacity (PCC), real carrying capacity (RCC) and effective carrying capacity (ECC) of Pattaya beach and Chalatat beach (Tables 2 and 3) [7]. PCC is calculated from dividing beach areas by area required per user and rotation factor. RCC is the PCC multiplied by the correction factors. ECC was the RCC multiplied by the management capacity $[5,18]$.

Table 2. Pattaya beach.

\begin{tabular}{cccccc}
\hline Scenario & Shoreline Retreat $(\mathbf{m})$ & Beach Area $\left.\mathbf{( m}^{\mathbf{2}}\right)$ & PCC & RCC & ECC \\
\hline 30 December 2017 (Past) & - & 54,480 & 145,280 & 103,487 & 72,441 \\
16 February 2019 (Present) & - & 153,373 & 408,995 & 291,339 & 203,937 \\
RCP 2.6 & -19.70 & 103,716 & 276,575 & 197,013 & 137,909 \\
RCP 4.5 & -24.35 & 92,011 & 245,362 & 174,778 & 122,345 \\
RCP 6.0 & -25.13 & 90,057 & 240,151 & 171,067 & 119,747 \\
RCP 8.5 & -33.08 & 70,019 & 186,717 & 133,004 & 93,103 \\
\hline
\end{tabular}

Table 3. Chalatat beach.

\begin{tabular}{cccccc}
\hline Scenario & Shoreline Retreat $(\mathbf{m})$ & Beach Area $\left.\mathbf{( m}^{\mathbf{2}}\right)$ & PCC & RCC & ECC \\
\hline 9 July 2017 (Past) & - & 196,946 & 143,233 & 77,307 & 38,653 \\
6 August 2018 (Present) & - & 253,666 & 184,484 & 99,571 & 49,786 \\
RCP 2.6 & -22.76 & 137,272 & 99,834 & 53,883 & 26,942 \\
RCP 4.5 & -28.05 & 112,529 & 81,839 & 44,171 & 22,085 \\
RCP 6.0 & -28.84 & 108,832 & 79,150 & 42,719 & 21,360 \\
RCP 8.5 & -37.58 & 67,877 & 49,365 & 26,644 & 13,322 \\
\hline
\end{tabular}

\subsubsection{Hotel Room Price}

Hotel attributes [16] in the study areas were collected from the websites www.booking. com (accessed on 19 June 2018) and www.agoda.com (accessed on 19 June 2018) for the units. These are online sites for booking the hotels, and were used as the source of empirical observation between 13 and 20 January 2019 (Table 4). There are 204 hotels at Pattaya beach spread along $2.84 \mathrm{~km}$, and 14 hotels at Chalatat beach spread along $4.06 \mathrm{~km}$ within $5 \mathrm{~km}$ offset from the beach.

Table 4. Hotel attribute variables.

\begin{tabular}{cl}
\hline Variable & Description \\
\hline Price & Room price in USD (two people for seven nights) \\
Beach width & Width in meters of the beach \\
Hotel stars & Star rating system $(1-5$ stars $)$ \\
Room size & Size of a hotel room in $\mathrm{m}^{2}$ \\
Breakfast & $=1$ if breakfast is included \\
Deluxe room & $=1$ if the room is described as a deluxe room \\
Superior room & $=1$ if the room is described as a superior or suite room \\
Mountain view & $=1$ if there is a mountain view \\
Sea view / Beach view & $=1$ if there is a sea view or beach view \\
City view & $=1$ if there is a city view \\
Kids' club & $=1$ if there is a kids' club \\
Balcony & $=1$ if the room has a balcony \\
Airport service & $=1$ if there is an airport shuttle bus service \\
Clean & $=1$ if there is a daily room cleaning service \\
Laundry & $=1$ if there is a laundry service \\
Location & $=1$ if the hotel is located on the desirable location \\
\hline
\end{tabular}




\subsubsection{Beach Nourishment Construction Cost}

Beach nourishment was adopted as the adaptation measure to cope with sea level rise at the two beaches. The quantity of beach nourishment was analyzed to retain the present condition of tourism carrying capacity.

The cost appraisal for sand in this study was estimated from the beach construction project at Pattaya beach and Chalatat beach. The sand cost was appraised at $23.21 \mathrm{USD} / \mathrm{m}^{3}$. The dune height and beach length of the study areas are shown in Table 5. The construction cost (present value) was determined from dune height, beach length, shoreline retreat, and sand appraisal per cubic meter (Tables 6 and 7). The maintenance cost of the beach nourishment project was estimated using a Marine Department of Thailand report $[19,20]$ and was calculated at 34,000 USD/y.

Table 5. Dune height and beach length.

\begin{tabular}{ccc}
\hline Study Areas & Dune Height (m.MSL) & Beach Length $(\mathrm{m})$ \\
\hline Pattaya beach & +4.5 & 2845 \\
Chalatat beach & +2.5 & 4060 \\
\hline
\end{tabular}

Table 6. Beach nourishment construction cost of Pattaya beach.

\begin{tabular}{ccc}
\hline Scenario & Shoreline Retreat $(\mathbf{m})$ & Construction Cost (USD) \\
\hline RCP 2.6 & -19.70 & $5,854,439$ \\
RCP 4.5 & -24.35 & $7,236,325$ \\
RCP 6.0 & -25.13 & $7,468,125$ \\
RCP 8.5 & -33.08 & $9,830,703$ \\
\hline
\end{tabular}

Table 7. Beach nourishment construction cost of Chalatat beach.

\begin{tabular}{ccc}
\hline Scenario & Shoreline Retreat $(\mathbf{m})$ & Construction Cost (USD) \\
\hline RCP 2.6 & -22.76 & $5,362,442$ \\
RCP 4.5 & -28.05 & $6,608,809$ \\
RCP 6.0 & -28.84 & $6,794,940$ \\
RCP 8.5 & -37.58 & $8,854,155$ \\
\hline
\end{tabular}

\subsubsection{Seawall Construction Cost}

There are many seawall construction projects aiming to protect the coastal areas in Thailand. Most of them are projects from the government. The construction cost was collected as the budget project from Thai government spending system (https:/ / govspending.data.go.th; accessed on 1 September 2020). The average seawall construction cost is 3,231,642 USD $/ \mathrm{km}$. Thus, the seawall construction cost of Pattaya beach and Chalatat beach were assessed by multiplied beach length with seawall construction cost as shown in Table 8.

Table 8. Seawall construction cost.

\begin{tabular}{ccc}
\hline Study Areas & Beach Length $(\mathbf{m})$ & Construction Cost (USD) \\
\hline Pattaya beach & 2845 & $8,402,268$ \\
Chalatat beach & 4060 & $12,926,567$ \\
\hline
\end{tabular}

\subsubsection{Setback Compensation Cost}

Compensation cost for setback was evaluated by the damage cost, which are the land prices and construction cost. The damage cost was estimated from the Google Earth images and the erosion of shoreline changes analysis, based on the effect of sea-level rise. In this study, the shoreline change from sea-level rise will affect the road and parking courtyard. The standard of infrastructure construction price list for the government compensation 
(Table 9) was examined by the Valuers Association of Thailand (http:/ / www.vat.or.th; accessed on 15 January 2021).

Table 9. The structure of infrastructure construction price list.

\begin{tabular}{cc}
\hline Areas Type & Construction Cost (USD/m $\left.{ }^{2}\right)$ \\
\hline Concrete road & 40 \\
Concrete courtyard & 23 \\
\hline
\end{tabular}

\section{Methods}

\subsection{Detection of the Shoreline Changes}

Satellite images from Google Earth were used to detect shoreline change. The tidal correction method corrected the captured time of images for the effect of tide on the position of the waterline relative to shoreline position [21,22]. Image processing is a technique used to analyze the shoreline position from pixels in the images. The satellite images were rectified with ground control points (GCPs), and the shoreline positions were detected with MATLAB software version 9.4 (accessed on 22 June 2020) [23]. The shoreline change rates were calculated using the different of shoreline positions in the consecutive time periods.

\subsection{Hedonic Price Method}

We used the hedonic pricing method of Lancaster [24] and Rosen [16], which identifies the attributes that affect the price of differentiated and compound products. This study aimed to evaluate the relationship between the price of a hotel room and the series of attributes described in Table 4 by generating a set of implicit prices for each attribute. The log-linear hedonic pricing regression is defined as follows:

$$
P_{i}=f_{i}\left(q_{i 1}, q_{i 2}, q_{i 3}, \ldots q_{i n}\right)
$$

In this equation, $P_{i}$ is the price of the hotel room, and $q_{i}$ represents the set of hotel attributes.

\subsection{Benefit-Cost Analysis}

The profitability of the investment project was assessed with a benefit-cost ratio $(B C R)$, which is calculated using the present value of benefits divided by the present value of costs.

$$
B C R=\frac{\sum_{t=0}^{T} \frac{B_{t}}{(1+r)^{t}}}{\sum_{t=0}^{T} \frac{C_{t}}{(1+r)^{t}}}
$$

In the equation for $B C R, B_{t}$ is the benefit at time $t, C_{t}$ are the costs at time $t, r$ is the discount rate, and $T$ is the time at the end of the study period. If $B C R$ exceeds 1 , the project is expected to return a positive net present value to the investor.

\section{Results and Discussions}

\subsection{Historical and Projected Shoreline Changes}

The historical shoreline change rates of Pattaya beach (Figures 2 and 3) and Chalatat beach (Figures 4 and 5) are shown in Figures 6 and 7, respectively. The average shoreline change rates had positive values of $0.09 \mathrm{~m} / \mathrm{y}$ in Pattaya and $0.59 \mathrm{~m} / \mathrm{y}$ in Chalatat. Deposition associated with seasonal and natural change occurred on these beaches. However, shoreline change rates have negative values in some years, so the beaches eroded during this time. Pattaya beach shoreline changes before the beach nourishment construction (2002-2017) had positive shoreline change rates, but it increased to a greater extent after the beach nourishment construction was installed. The historical shoreline change rates were analyzed for the background of beach dynamics overtime. It will not apply in the analysis of future beach loss. 


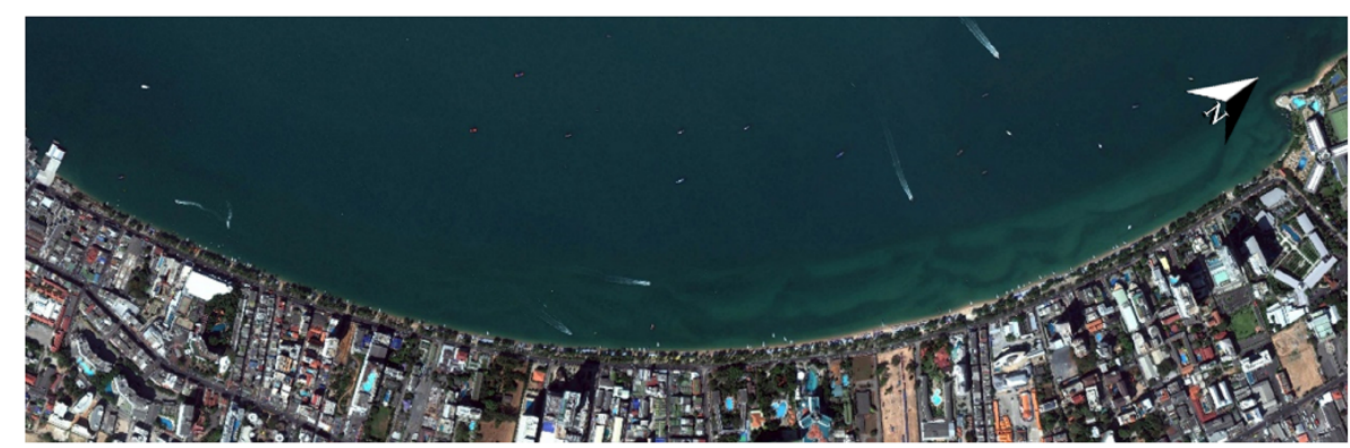

Figure 2. Pattaya beach.

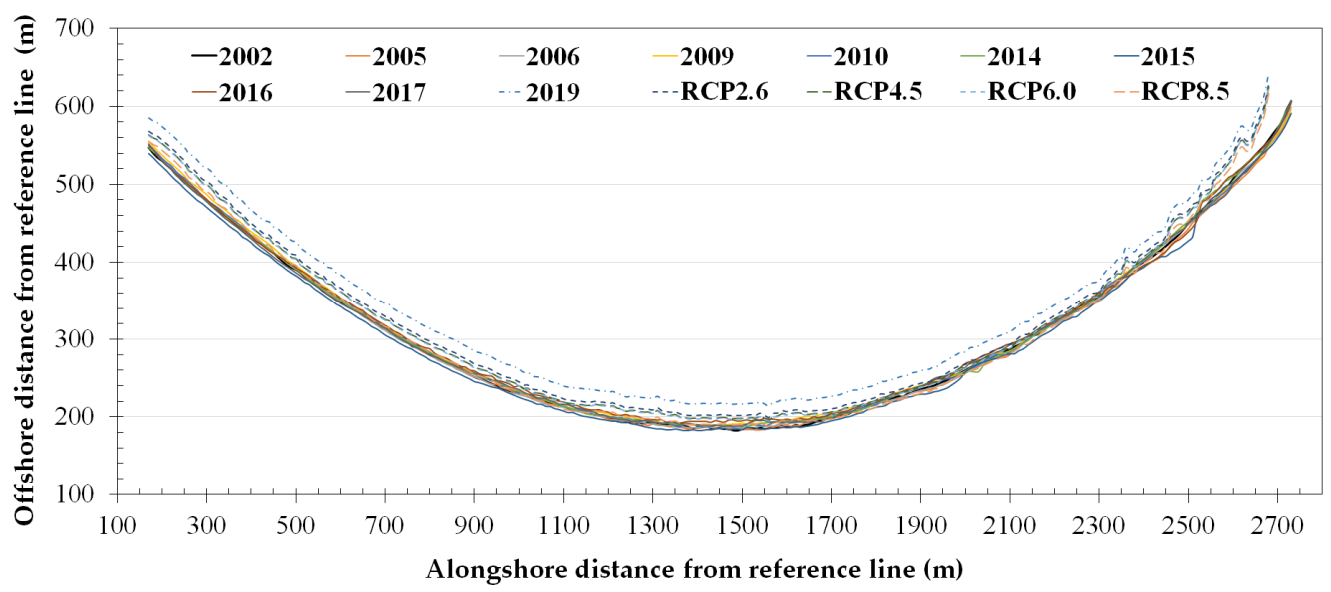

Figure 3. Shoreline position of Pattaya beach.

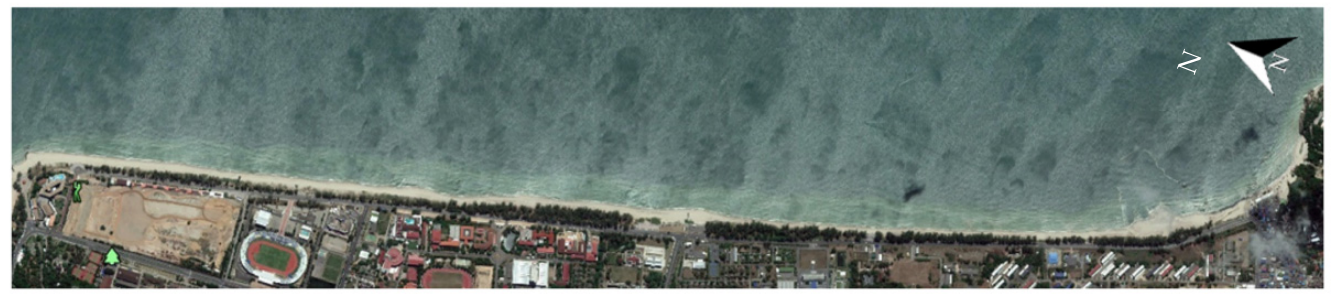

Figure 4. Chalatat beach.

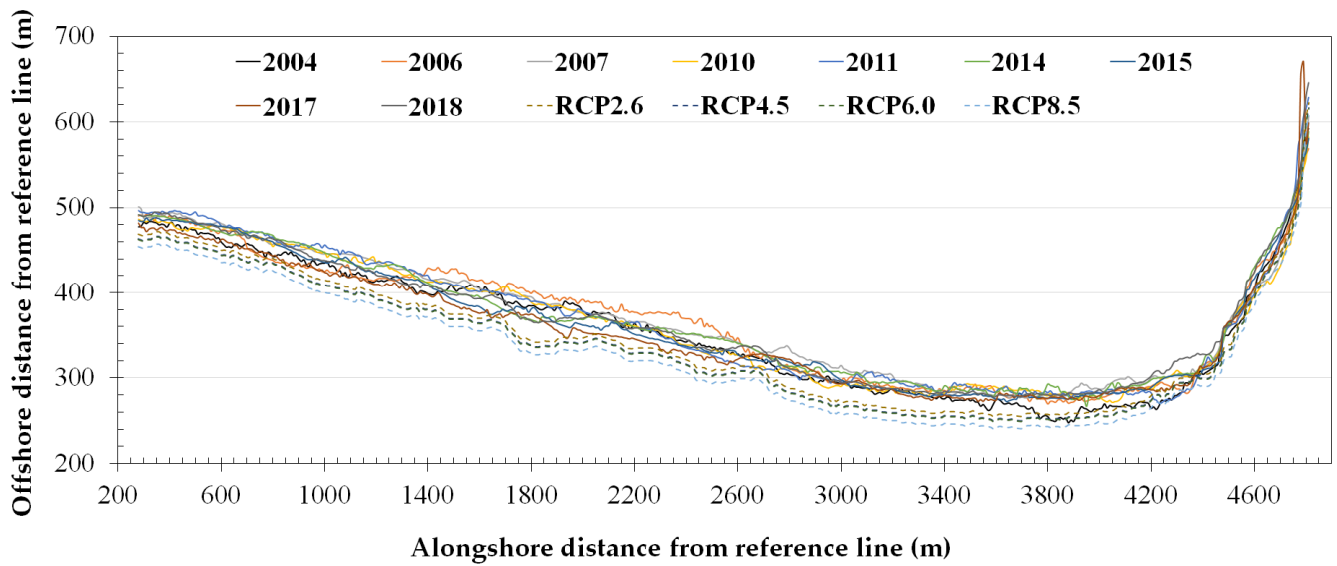

Figure 5. Shoreline position of Chalatat beach. 


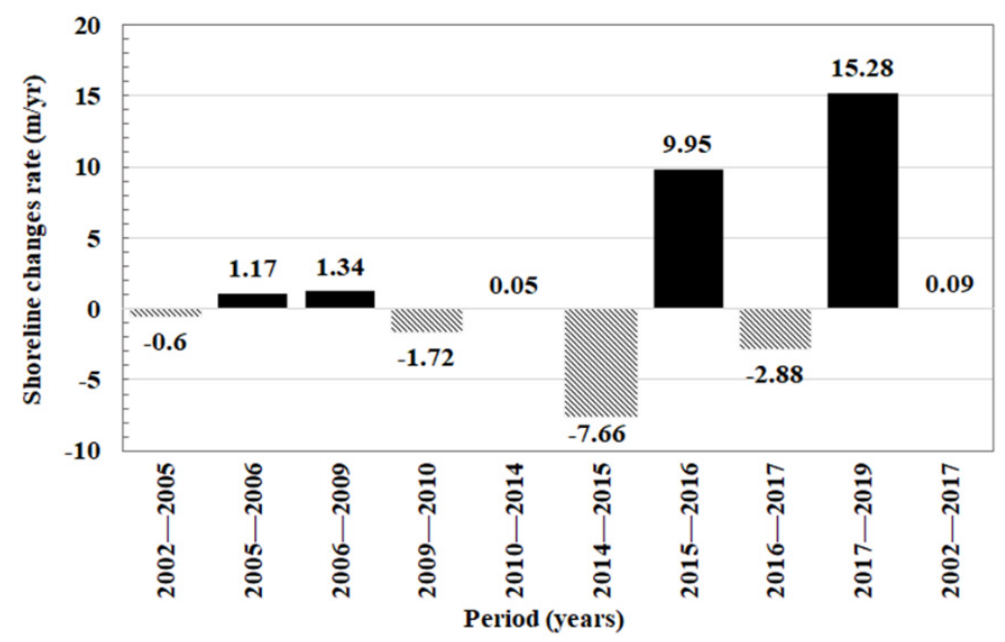

Figure 6. Rate of shoreline change at Pattaya beach.

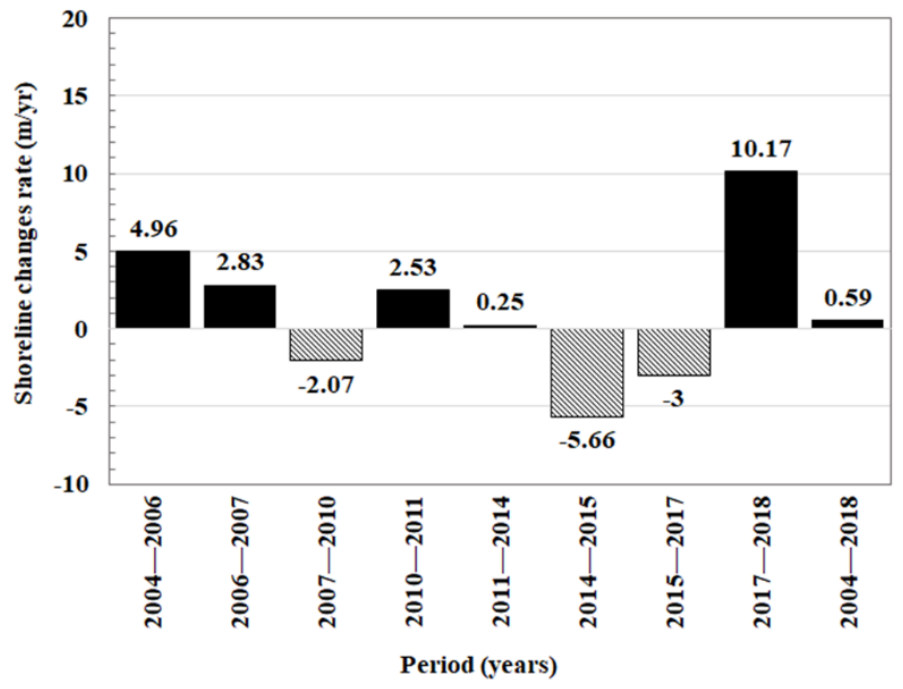

Figure 7. Rate of shoreline at Chalatat beach.

The projected shoreline change due to sea level rise was analyzed with the Bruun rule in a previous study [7]. Based on the present conditions, the average shoreline retreat at Pattaya beach was $19.70 \mathrm{~m}$ for RCP 2.6 and $33.08 \mathrm{~m}$ for RCP 8.5. At Chalatat beach, the average shoreline retreat was $22.76 \mathrm{~m}$ for RCP 2.6 and $37.58 \mathrm{~m}$ for RCP 8.5. Projected shoreline changes due to sea level rise are less than the historical shoreline changes at Pattaya beach, because of the completion of beach nourishment in 2019 (Figures 3 and 5). In contrast, projected shoreline changes were greater than historical shoreline changes at Chalatat beach. Through this analysis, we confirmed that beach nourishment is a viable solution to deal with beach loss due to sea level rise.

\subsection{Beach Values from Hedonics Pricing Method}

Using the hedonic pricing method, the coefficient of the variable "Sea view/Beach view" is 0.3335 . This suggests that the price of hotel room is $40 \%$ higher in the rooms with a sea view or a beach view (from $\ln e^{\beta}-1$, when $\beta$ is the coefficient of "Sea view/Beach view" attribute). The beach value of Pattaya beach and Chalatat beach presented in Table 10 are based on the occupancy rates and the number of tourists obtained from the Ministry of Tourism and Sports in 2018. The study areas were detected using 2018 Google Earth images, and the currency exchange rate in 2018 was 32.932 Thai Baht $=1$ USD. The number of tourists and the beach area affected the high value of the beach at Pattaya beach. 
Table 10. Beach value.

\begin{tabular}{ccccc}
\hline Study Areas & Occupancy (\%) & Number of Tourists (Person/y) & Beach Area (m ${ }^{\mathbf{2}}$ ) & Beach Value (USD) \\
\hline Pattaya beach & 77.91 & $14,680,669$ & 44,270 & $1,072,250$ \\
Chalatat beach & 73.72 & $7,635,378$ & 253,666 & 92,092 \\
\hline
\end{tabular}

\subsection{Benefit-Cost of Adaptation Measures}

Tables 11 and 12 present the benefit-cost ratio analysis of Pattaya beach and Chalatat beach. The benefits and costs of beach nourishment and seawalls were evaluated from a future value in 2100 and transferred into the present value, assuming that benefits were associated with the same conditions every year. The cost of the setback method was estimated from the beach value and damage cost of the land and infrastructure.

Table 11. Benefit-cost ratio analysis of Pattaya beach.

\begin{tabular}{|c|c|c|c|c|c|c|c|c|c|}
\hline Scenario & $\begin{array}{l}\text { Benefit of } \\
\text { Beach Nour- } \\
\text { ishment } \\
\text { (USD) }\end{array}$ & $\begin{array}{l}\text { Cost of } \\
\text { Beach Nour- } \\
\text { ishment } \\
\text { (USD) }\end{array}$ & $\begin{array}{l}\text { B/C Ratio of } \\
\text { Beach Nour- } \\
\text { ishment }\end{array}$ & $\begin{array}{l}\text { Benefit of } \\
\text { Seawall } \\
\text { (USD) }\end{array}$ & $\begin{array}{c}\text { Cost of } \\
\text { Seawall } \\
\text { (USD) }\end{array}$ & $\begin{array}{l}\text { B/C Ratio of } \\
\text { Seawall }\end{array}$ & $\begin{array}{l}\text { Benefit of } \\
\text { Setback } \\
\text { (USD) }\end{array}$ & $\begin{array}{c}\text { Cost of } \\
\text { Setback } \\
\text { (USD) }\end{array}$ & $\begin{array}{c}\text { B/C Ratio of } \\
\text { Setback }\end{array}$ \\
\hline RCP 2.6 & $15,966,319$ & 513,346 & 31.1024 & $15,966,319$ & $9,727,201$ & 1.6414 & 0 & $15,966,319$ & - \\
\hline RCP 4.5 & $15,966,319$ & 518,199 & 30.8112 & $15,966,319$ & $9,727,201$ & 1.6414 & 0 & $15,966,319$ & - \\
\hline RCP 6.0 & $15,966,319$ & 519,013 & 30.7628 & $15,966,319$ & $9,727,201$ & 1.6414 & 0 & $15,966,319$ & - \\
\hline RCP 8.5 & $15,966,319$ & 527,311 & 30.2788 & $15,966,319$ & $9,727,201$ & 1.6414 & 0 & $15,966,319$ & - \\
\hline
\end{tabular}

Table 12. Benefit-cost ratio analysis of Chalatat beach.

\begin{tabular}{|c|c|c|c|c|c|c|c|c|c|}
\hline Scenario & $\begin{array}{l}\text { Benefit of } \\
\text { Beach Nour- } \\
\text { ishment } \\
\text { (USD) }\end{array}$ & $\begin{array}{l}\text { Cost of } \\
\text { Beach Nour- } \\
\text { ishment } \\
\text { (USD) }\end{array}$ & $\begin{array}{l}\text { B/C Ratio of } \\
\text { Beach Nour- } \\
\text { ishment }\end{array}$ & $\begin{array}{l}\text { Benefit of } \\
\text { Seawall } \\
\text { (USD) }\end{array}$ & $\begin{array}{l}\text { Cost of } \\
\text { Seawall } \\
\text { (USD) }\end{array}$ & $\begin{array}{c}\text { B/C Ratio of } \\
\text { Seawall }\end{array}$ & $\begin{array}{l}\text { Benefit of } \\
\text { Setback } \\
\text { (USD) }\end{array}$ & $\begin{array}{c}\text { Cost of } \\
\text { Setback } \\
\text { (USD) }\end{array}$ & $\begin{array}{c}\text { B/C Ratio of } \\
\text { Setback }\end{array}$ \\
\hline RCP 2.6 & $1,371,299$ & 511,618 & 2.6803 & $1,371,299$ & $14,964,924$ & 0.0916 & 0 & $1,371,299$ & - \\
\hline RCP 4.5 & $1,371,299$ & 515,995 & 2.6576 & $1,371,299$ & $14,964,924$ & 0.0916 & 0 & $1,374,346$ & - \\
\hline RCP 6.0 & $1,371,299$ & 516,649 & 2.6542 & $1,371,299$ & $14,964,924$ & 0.0916 & 0 & $1,374,933$ & - \\
\hline RCP 8.5 & $1,371,299$ & 523,881 & 2.6176 & $1,371,299$ & $14,964,924$ & 0.0916 & 0 & $1,419,602$ & - \\
\hline
\end{tabular}

There were no benefits for the setback method at either of the two beaches. When the $B C R$ is greater than 1, the adaptation measure is worth the investment. The $B C R$ of beach nourishment and seawalls at Pattaya beach is higher than at Chalat beach because Pattaya beach provides greater benefits than Chalatat beach, due to its higher beach value.

The benefit, cost and $B C R$ of setback shown that it is not worth taking no action with the tourism beaches when the sea level is rising. However, the setback method will be suitable for the beaches which were not used for the tourism as the main advantage, because those beaches will not have great beach value based on the hotel room prices.

\section{Conclusions}

Natural and human activities make coastal areas extremely dynamic. In the 21st century, global sea levels will rise due to climate change, which will cause shorelines to retreat and this will affect beach areas that provide human and ecosystem benefits. Adaptation measures present a solution that protects against beach loss and helps maintain beach TCC. In Thailand, structural measures to protect beaches have been widely used, but these efforts also affect nearby coastal areas, forcing other beaches unsuitable for tourism to be used. On the other hand, beach nourishment increases the beach width and promotes recreation on tourism beaches. This study analyzed the historical shoreline changes from satellite images, and evaluated the beach value using the hedonic pricing method. The benefit-cost ratio analysis was used to assess the economic valuation assessment. It was identified that the average shoreline change rates have a positive value in these two study areas. The price of a hotel room is higher by $40 \%$ in rooms with a sea view. In addition, the beach values of Pattaya beach and Chalatat beach are 1,072,250 and 92,092 USD, respectively. For the overall value of the beach, this estimate is the lower bound calculated from the indirect valuation method. The $B C R$ of seawalls is smaller than that of beach nourishment. The $B C R$ 
analysis suggests that it is worth implementing beach nourishment to mitigate against the effects of climate change. On the other hand, it is necessary to evaluate the environmental impact assessment and sand resources before the implementation of beach nourishment. Moreover, the monitoring of impacts from beach nourishment projects ought to be carried out cautiously. In addition, $B C R$ of setback shows that it is not worth retreating when the sea level is rising. The results will be useful in the process of preliminary decision making for the policymakers.

Author Contributions: Project administration, S.R.; supervision, S.R., K.U. and H.S.; validation, S.R.; formal analysis, P.N.; data curation, P.N.; writing-original draft preparation, P.N. and S.R.; writing-review and editing, S.R. and P.N. All authors have read and agreed to the published version of the manuscript.

Funding: This research received no external funding.

Acknowledgments: This research was supported by Advancing Co-design of Integrated Strategies with Adaptation to Climate Change on Thailand (ADAP-T) supported by the Science and Technology Research Partnership for Sustainable Development (SATREPS), JST-JICA.

Conflicts of Interest: The authors declare no conflict of interest.

\section{References}

1. IPCC. Working Group I Contribution to the IPCC Fifth Assessment Report Climate Change 2013, the Physical Science Basis; Final Draft Underlying Scientific-Technical Assessment IPCC, Stockholm; Cambridge University Press: Cambridge, UK, 2013.

2. Patcharapitchakorn, K.; Ritphring, S. Sea Level Change in Thailand. Ladkrabang Eng. J. 2012, $29,56-60$.

3. Ritphring, S.; Somphong, C.; Udo, K.; Kazama, S. Projections of Future Beach Loss due to Sea Level Rise for Sandy Beaches along Thailand's Coastlines. J. Coast. Res. 2018, 85, 541-545. [CrossRef]

4. Zacarias, D.A.; Williams, A.T.; Newton, A. Recreation carrying capacity estimations to support beach management at Praia de Faro, Portugal. Appl. Geogr. 2011, 31, 1075-1081. [CrossRef]

5. Sridhar, R.; Yuvaraj, E.; Sachithanandam, V.; Mageswaran, T.; Purvaja, R.; Ramesh, R. Tourism Carrying Capacity for Beaches of South Andaman Island, India. Tour. Empir. Res. Pract. Appl. 2016, 61. [CrossRef]

6. Hamed, H.K.; Fataei, E. Estimation of tourism carrying capacity of Fandoqloo Forest in Ardebil Province, Iran. Bull. Environ. Pharmacol. Life Sci. 2013, 2, 64-70.

7. Nidhinarangkoon, P.; Ritphring, S.; Udo, K. Impact of Sea Level Rise on Tourism Carrying Capacity in Thailand. J. Mar. Sci. Eng. 2020, 8, 104. [CrossRef]

8. Campbell, T.J.; Benedet, L. Beach nourishment magnitudes and trends in the U.S. J. Coast. Res. 2006, 39, 57-64.

9. Morán, D.K.; Salles, A.; de A, P.; Sánchez, J.C.; Espinal, J.C. Beach nourishment evolution in the Cancun beach, Quintana Roo, Mexico. Coast. Sediments 2007, 7, 2279-2291.

10. Sano, M.; Jiménez, J.A.; Medina, R.; Stanica, A.; Sanchez-Arcilla, A.; Trumbic, I. The role of coastal setbacks in the context of coastal erosion and climate change. Ocean Coast. Manag. 2011, 54, 943-950. [CrossRef]

11. Portman, M.E.; Esteves, L.S.; Le, X.Q.; Khan, A.Z. Improving integration for integrated coastal zone management: An eight country study. Sci. Total Environ. 2012, 439, 194-201. [CrossRef] [PubMed]

12. Fenster, M.S. Setbacks. In Encyclopedia of Coastal Science; Schwartz, M.L., Ed.; Springer: Dordrecht, The Netherlands, 2012; pp. 863-866.

13. Kraus, N.C. The effects of seawalls on the beach: An extended literature review. J. Coast. Res. 1988, 4, 1-28.

14. Charusrojthanadech, N. Effect of Coastal Prevention by Beach and Serious Problems in Some Coasts of the Gulf of Thailand. In Proceedings of the Twenty-First International Offshore and Polar Engineering Conference, International Society of Offshore and Polar Engineers, Maui, HI, USA, 19-24 June 2011.

15. Plant, N.G.; Griggs, G.B. Interactions between nearshore processes and beach morphology near a seawall. J. Coast. Res. 1992, 8, 183-200.

16. Rosen, S. Hedonic prices and implicit markets: Product differentiation in pure competition. J. Political Econ. 1974, 82, 34-55. [CrossRef]

17. Fleischer, A. A room with a view-A valuation of the Mediterranean Sea view. Tour. Manag. 2012, 33, 598-602. [CrossRef]

18. Bera, S.; Majumdar, D.D.; Paul, A. Estimation of tourism carrying capacity for Neil Island, South Andaman, India. J. Coast. Sci. 2015, 2, 46-53.

19. Marine Department of Thailand. The Master Plan of Beach Nourishment Construction in Pattaya Beach; Marine Department of Thailand: Chonburi, Thailand, 2010. (In Thai)

20. Marine Department of Thailand. The Detail Design of Beach Nourishment Construction in Chalatat Beach; Marine Department of Thailand: Songkhla, Thailand, 2013. (In Thai)

21. Boak, E.H.; Turner, I.L. Shoreline definition and detection: A review. J. Coast. Res. 2005, 21, 688-703. [CrossRef] 
22. Hoang, V.; Tanaka, H.; Mitobe, Y. A method for correcting tidal effect on shoreline position extracted from an image with unknown capture time. Geosciences 2017, 7, 62. [CrossRef]

23. Nidhinarangkoon, P.; Ritphring, S.; Tanaka, H. Shoreline changes by using google earth images with tidal correction: A case study of samui island, Thailand. In International Conference on Fluid Mechanics 8; Tohoku University: Sendai, Japan, 2018.

24. Lancaster, K.J. A new approach to consumer theory. J. Political Econ. 1966, 74, 132-157. [CrossRef] 